\title{
THE POSITION OF LOW MALAY SHORT STORIES IN THE HISTORY OF INDONESIAN LITERATURE
}

\author{
Pujiharto $^{1}$, Sudibyo ${ }^{1}$ \\ ${ }^{1}$ Indonesian Department, Faculty of Cultural Sciences, Universitas Gadjah Mada \\ Email: pujiharto@ugm.ac.id
}

\begin{abstract}
This article tries to determine the factors causing the Low Malay short stories became unaccounted, especially those that were collected in Miss Koelit Koetjing (2005), in the constellation of the history of modern Indonesian literature. To answer these problems, this paper explores the criteria applied by the author of the history of Indonesian literature, comparing it with the Low Malay short stories, and relates them to their cultural historical context.

The results showed the reason that Low Malay short stories collected in Miss Koelit Koetjing were not accounted, are caused by the following factors. First, most of the short stories still retain the traditional genres, such as hikayat (saga) and fairy tales, which show the strength of the cultural orientation of the past. Second, the authors of short stories are not natives; the author is not in the sense of the creator, the creator, but a storyteller, just to recount a story that has been there before. Third, short stories were published in newspapers and not in the book form. Fourth, the world of their stories came from diverse cultures and not from the world of the Indonesian archipelago.

With a similar reality, it can be concluded that the short stories collected in Miss Koelit Koetjing, in the broad realm of Low Malay literature, is a literary tradition of its own in the constelation history of Indonesian literature.
\end{abstract}

Keywords: literary criteria, Low Malay short stories, modern Indonesian literature

\section{INTRODUCTION}

It has been more than half a century, the study of Low Malay literature ${ }^{1}$-short story as one of the objects of study - was conducted by some experts of literature. Initially the study was conducted by Nio Joe Lan (1962) with his book entitled Sastra Indonesia Tionghoa. Through the book Lan brought out evidences of the role of Chinese Indonesian literature in the establishment of Indonesia. With those evidences, Lan would like to say that Chinese literature was there and contributed to the establishment of Indonesia and therefore it is also appropriate to say that Chinese literature is also co-recorded in the history of Indonesian literature. Lan's step was then followed by Salmon with his book entitled Sastra Cina Peranakan dalam Bahasa Melayu (1985) which was later reinforced by the publication of his next book, namely the Sastra Indonesia Awal Kontribusi Orang Tionghoa (2010), which affirmed that the quantity of Chinese Peranakan literature circulating in the Dutch East Indies, is a fact that cannot be denied, and hence be reckoned as part of Indonesian literature, and thus it is fit tobe recorded in the history of Indonesian literature. Similar efforts were also carried out by the Popular Library Publisher Gramedia with the publication of a book entitled Kesusastraan Melayu Tionghoa dan Kebangsaan Indonesia (2000), which was then welcomed with research efforts conducted by the Center for Language team under 
the leadership of Sapardi Djoko Damono whose research was then recorded with the title Nona Koelit Koetjing Antologi Cerita Pendek Indonesia Periode Awal (1870-an-1910-an) (2005). Tit for tat, study on the same topic it is probably not a mere coincidence, but because in those topics contained a problem on the terms of international relations that needs to be further explored. Moreover, the study also could be interpreted as an attempt by researchers to take into account what was living in the past, the participation that was ever donated by the Chinese for the nation of Indonesia, efforts to fight for its existence in the present in the collective memory of the people of Indonesia in the form of being documented in the history of Indonesian literature. The struggle was evident in the statement of Melani (2005: 2), a member of the research team headed by Damono, in the introduction to Nona Koelit Koetjing, as follows:

These twenty stories are short stories published in the media in the Dutch East Indies before $19 \mathrm{r} \cdot$, which may be collected by the Research Project History of Indonesian Literature, Language Center. Why 19r.? The year of 19r. has been commonly used as a milestone in the birth of modern Indonesian literature, with the publication of the novels by Balai Pustaka, the adaptation work entitled Azab dan Sengsara by Merari Siregar. However, the whole process of research that resulted in this anthology shows that Indonesian literature has been produced and distributed much earlier.

By saying "that the Indonesian literature has been produced and distributed emuch earlier ", Melani is doing one form of the delegitimations of the view that has been long circulated that literature of Indonesia was born in 1920s, and tried, with the evidence of short stories that were anthologized, were short story of those Low Malay, offers a new view that Indonesian literature was born much earlier.

However, the effort of the expert of literature on top seems merely a discourse that is not fully or evens less to get a positive response from the stakeholders of Indonesian literature. Sumardjo, in the book of Kesusastraan Melayu Rendah Masa
Awal (2004: 6-7), states:

If the literature of Low Malay is still considered one of the literary genres that developed in parallel since the colonial era, then this literature should only be discussed in the literary history of the Low Malay, with the record that does not discriminate between nationalities, as it is already happening.

By stating "this literature should only be discussed in the literary history of the Low Malay", he stated that the Low Malay literature does not need to be discussed within the framework of modern Indonesian literature. However, on the contrary, on the next statement, Sumardjo (2004: 7) states that

But, if the Low Malay literarure, indeed, will be included as a part of the development of Indonesian literature, it is not only the works of native Low Malay that ought to be discussed, but also those of the Peranakans and the Netherlands

With this opinion, as it appears that Sumardjo is in a gray position, he did not fully support or reject the attempt to make the Low Malay literature as a part of the history of modern Indonesian literature. Sumardjo only put forward a logical consequence of a choice.

The Indonesian literature community, in contrast to the attitude of Sumardjo, tends to accept as a truth that the history of Indonesian literature that has been written by experts in advance of Indonesian literature, such as through the book of Sastra Indonesia Modern (1967), Rosidi in books of Ikhtisar Sedjarah Sa stra Indonesia (1976), and Siregar in Sedjarah Sastra Indonesia Modern (1964), did not include Low Malay literature as a part of the history of Indonesian literature ${ }^{2}$. The truth is supported by evidence that literary works noted by the previously mentioned experts is used as teaching material in textbooks from elementary school through High School and the literary works of Low Malay have not been used as teaching materials in these books.

The inclusion of a literary work in the literary history of Indonesian literature is necessarily based on certain criterias. In the context of the writing of the history of Indonesian literature, the 
criteria referred to seems inseparable from the Indonesianess criteria. Indonesia as the root of Indonesianess in the context of the writing of the history of Indonesian literature's efforts appear to be inseparable from the notion Indonesia within the framework of nation-building, which is the modern day Indonesia. The sense of modern itself also cannot be separated from its emergence in Europe, a condition characterized by a shift from the original pendulum God-centered (theocentric) to a human-centered (anthropocentric) (Habermas, 1990). Therefore, the establishment of modern Indonesia cannot be separated from the role of the subject of modernity, which is none other than the Europeans themselves. Thus, the regulation is applied in determining the inclusion of an Indonesian literary works more or less influenced by modern criteria according to the European perspective.

The above criteria can be seen from the arguments put forward in the Teeuw's book Indonesian Modern Literature, a Dutch orientalist whose view regarding Indonesian literature, especially the Indonesian literary history, has a strong influence in the study of Indonesian literature. In the readings by Pujiharto (2014) against the Teeuw's book, there were several criterias that he used. First, there is a deviation in the form of changes from the traditional literary formulas to the modern literature. The deviation of this formula is a consequence of the influence of Western culture, in particular the Netherlands to the indigenous people. The process of irregularities that occurred in the 1920s was written with a basic framework that is Indonesia-ish, both in terms of language and race. It was before the decision to establish Bahasa Indonesia, that bahasa reffered before pointed to a Bahasa of High Malay. Second, the authors of literary works Indonesia are the native people. What are meant by "natives" are people who come from regions at a later part of the territory of Indonesia and the descendants of the local area. The author in question is the author within the meaning of the creator, the creator, so their work is original; not the author in the sense of a storyteller, which is only to recount the stories of others. Third, the relevant literatures were published by Balai Pustaka, the colonial government formation institutions that acted as censors of quality literary works. According to Mahayana (2006: 5), literature published by Balai Pustaka was printed in the book form.

The criteria are applied with regard to the Balai Pustaka's published literature which could include the following: (1) The published literature was about suiting the tastes of the consumer society; (2) the resulted readings should be able to contribute to the knowledge of the society; (3) the produced readings should enable the people to combat ignorance; (4) the resulted readings should be able to distance the public from things that could damage the government's power and peace in the country (Damono via Faruk, 1999: 114-115).

The Low Malay literature being not included in the literary history of Indonesia is certainly due to the works in question does not meet the above criteria. However, the use of term "literature" to refer to the Low Malay stories implicitly indicates the recognition that Low Malay short story is a literary work. Even Melani (2005), calls it "the beginning of Indonesian literature." It means that those work certainly inherent literary criteria. In connection with that, the important question raised was what is the literary characteristics of The Low Malay short story? By knowing the literatury characteristic attached to the short story, it is expected that the factors that cause the exclusion of the short stories in the history of Indonesian literature could be known. Or it could be, in fact these short stories, like that opinion of Faruk et al. (2000), is a part of the different traditions of the literary tradition which was later recognized as part of the history of Indonesian literature.

To know the characteristics of Low, Malay short stories, the undertaken steps are as follows. First, to do the reading repeatedly on the stories studied by focusing on intra and extra aesthetic characteristics. Second, to identify the characteristics of these short stories and compare it with the criteria of Indonesian literature that has been formulated either by Teeuw and the Balai Pustaka. The comparison is intended, in addition to determining whether the characteristics of the Low Malay short story is in accordance with these criteria, as well as to scrutinize whether the predetermined criteria is consistent with the Indonesian spirit, both with regard to the formation of the language or the Indonesia as a nation. Third, 
to discuss the comparison in associate with the condition of literature, both the oral literature and the classical Malay literature, also the condition of socio-cultural changes ongoing at that time. Fourth, is to draw conclusions.

\section{CHARACTERISTICS INTRA-NARRATIVE SHORT STORY SHORT STORY IN NONA KOELIT KOETJING}

The short stories collected in Nona Koelit Koetjing have the elements of intra narrative in general, which is according to Stanton (1965), include the facts, the means, and the theme of the story. The elements are processed in a certain way to awaken a fictional world, the world that characterizes a literary work. However, those short stories were not processed in such way that it has the characteristics of a modern short story according to the Teeuw's criteria above. That short story actually has the following traditional characteristics.

\section{In the form of Hikayat (Saga)}

There are two short stories whose title is the name of the hikayat, namely "“Hikajat AmalBeramal" dan "Ihajat Tanah Djawa".Surprisingly, despite its title is hikayat, these two stories' length are short, not in the form of long prose as such in a hikayat (saga) in general. "Hikajat Amal-Beramal" is not a story about the journey of a hero who came from royal palaces such as in the general saga, but it tells the story of everyday lives, about Chinese and Muslim whose money which is the result of hard work, depleted for only religious purposes; a story which is an allusion to the Chinese people and the Moslem.

"Ihajat Tanah Djawa" is indeed a story about the world of the palace, the palace of the Roman Empire. Unlike a hikayat in general, which tells of a knight in particular, this ihajat tells the tale of a royal palace soldier sent for the king's conquest of the ruler of Java. In these two hikayat, there is a slight deviation from the understanding that how a hikayat previously understood.

\section{In the Form of Fairy Tales}

Apart int the form of hikayat, there is also a short story in the form of a fairy tale, that of "Tjerita
Saorang Saoedagar Jang Bernama Talip”," Malaikat Djibrail dan Doea Orang Bersaoedara Satoe Dongeng dari Negeri Arab", "Androclus dan Satoe Singa”, "Apa jang Terlanggar Mendjadi Mas (Bagiannja orang jang seraka)", "Tjerita dari Satoe Poehoen Mangga", "Nona 'Koelit Koetjing"”.

Very much like hikayat, fairy tale genre also faced similar fate. Unlike the widely recognizable form as traditional prose genre that is in a long form, in this collection, tales are in short story form. However, the didactic nature of fairy tales is still strongly embedded inside. The entire short stories genre of fairytale above teach readers to have moral attitudes that correspond to the message the story told: Do not cheat! ("Tjerita Saorang Saoedagar Jang Bernama Talip"), care to the social environment around you! ("Malaikat Djibrail dan Doea Orang Bersaoedara Satoe Dongeng dari Negeri Arab"), do not be vengeful! ("Androclus dan Satoe Singa"), do not be greedy! ((“Apa jang Terlanggar Mendjadi Mas (Bagiannja orang jang seraka))", do not easily punish ("Tjerita dari Satoe Poehoen Mangga"), care to the poor (" Nona 'Koelit Koetjing' ").

Despite the irregularities, which also mean that there is a change, but the change is only with respect to its form, while in terms of content, it is not a significant change. It shows that the author has a cultural orientation to the past and not to the future that is the hallmark of a modern perspective. In the light of Teeuw's perspective above, the use of the traditional genre shows that this form of literary expression was not changed previously. Similar orientation was seen as less support for efforts to establish the Indonesian language and culture which are modern and advanced. It is a similar fact that seems to be one of the causes of why these short stories were not recorded as a part of the history of modern Indonesian literature.

\section{EXTRA NARRATIVE CHARACTERISTIC}

Besides having the characteristics of intra narratives, short stories collected in this Nona Koelit Koetjing have the characteristics of extra narrative that do not comply with the criteria set forth above by Teeuw. Extra narrative characteristics are as follows. 


\section{Author: Non-Natives, Anonymous, Story Teller}

Authors collected in the Nona Koelit Koetjing (2005), all of them are non-native. From the names, it appears that they all were Chinese Peranakan, like Thio Liang Hin, or Europeans like H.F.R. Kommer. Similarly, the authors are anonymous or disguised. ${ }^{3}$

Authors who are non-natives, some of them were anonymous and some were partially written. With regard to the authors who wrote their names, partly wrote their real name, others used pseudonym. However, the names of the author were not in the sense of the creators, but as storytellers: they simply rewrote what they ever read, heard, and / or known (Melani, 2005: 12).

The stories that the author were anonymous are "Hikajat Amal-Beramal", "Ihajat Tanah Djawa", "Tjerita Saorang Saoedagar yang bernama Talip", "Dari Khitsah Perdjalanan Abdoellah Pergi Melihat Tentehoewi", dan "Androclus dan Satoe Singa", "Tjerita dari Satoe Pohon Mangga".

The author who wrote their name is H.F.R. Kommer. Some of the stories that he rewrote are "Alksenoff atau Satoe Saoedagar jang Soedah Dihoekoem Tiada Berboeat Salah Satoe Tjerita dari Negeri Roes", "Di Toeloeng Saekor Andjing Satoe Tjerita dari Negeri Frans", "Henri Lest ataoe Habis Oejan Tentoe Panas Lagi", "Malaikat Djibrail dan Doea Orang Bersaoedara Satoe Dongeng dari Negeri Arab", "Nona Lizzij ataoe Saorang Prampoean Moeda Aloes Adat", "Prins Radjam Panahore Harganja Peroentoengan", "Si Marinem ataoe Mata Gelap". Besides Kommer, the storyteller whose name was written explicitly is Thio Liang Hin who wrote "Apa jang Terlanggar Mendjadi Mas",Juvenlie Kuo who wrote "Satoe Perboeatan Djahat Dibales dengen Kebaekan", and Touchstone who wrote "Nona Koelit Koetjing".

The authors whose name may appear to be pseudonym, are Orang Kecil who wrote "Aspirant Luitenant Tan Ping Tjiat dan Wak Tjoen Lee", Que who wrote "“'Itu Tasch jang Terisi dengen Inten" and Kawanan Penipoe jang Amat Pinter", Modern who wrote"Satoe Pertjobaan Boeat Adjar Kenal Hatinja dari Ia Poenja Bakal Soeami”.

The emergence of the phenomenon of anonymous authors and writers as storytellers apparently cannot be separated from the position of the newspaper as a medium of distribution. Short stories by the newspaper issue, was placed as a part of the overall newspaper's news. Stories selected for being published was a short story that has news value. Accordingly, what was required was not an author in the sense of the creator, but as the reporter. It is just that the news covered was not obtained from the direct sources, but from the stories that have been there before.

The phenomenon of the author as a storyteller is as also mentioned by Melani (2005), that come into one's vision as the characteristics of the oral tradition. However, when it is examined carefully, there are significant differences in both aspects: as for the oral tradition, the transmission process takes place orally (Bunanta, 1998), the short stories during the era of Low Malay, its process of transmission could be from oral to written or from the writing in certain areas to the writing in other areas. In the context of this paper, writing on another's territory in question points to a newspaper article.

Indeed, the tradition of authorship in classical Malay literature, literature that also lived at the same time, also put forward the anonymity of the author. However, in contrast to the anonymity of the author of the short story above or in the oral tradition, anonymity in classical Malay literature, according to Hamzah (1996: 2),

maybe, this way of composing is considered common in the past, was a thing that was in contra with religion, only that of the religious writing were commendable, other than that could be considered as futile came in vain and was not favored by the Islamic scholars (ulama).

The tradition of authorship who was marked by authors who were not native, who author portrayed himself as a storyteller or the anonymous author in the story, especially in the short story of Low Malay, above, is in contrast to the tradition of authorship in Indonesian literature, which lasted from Balai Pustaka, where the author must be natives, putting themselves as the creators; or when refers to the way the European point of view, the author is seen as frei denker or subjects who are free to determine its own right. The existence of the 
very opposite characteristics also seems to be one of the causes of exclusion Low Malay short stories as a part of the history of Indonesian literature.

\section{Short Stories in Newspaper}

In her introduction, Melani (2005) argues in detail beginning the publication of short stories collected in Nona Koelit Koetjing. Most of them were originally published in newspapers, in part, that the seven short stories in between, were written by H.F.R. Kommer, previously published in a collection. Nonetheless, as pointed out by Toer (2003: 38), H.F.R. Kommer ever worked as editor of Pewarta Soerabaia (issued in: Surabaya 1902-1942) and then also Primbon Soerabaia (rose and died: Surabaya 1900). This means that, in addition to also base on the stories in that which came from other countries (Europe, Arabia, India), short stories by H.F.R. Kommer contains very thick nuances of journalism. With such characteristics, the short stories by H.F.R. Kommer were not so much different from the characteristics of newspaper stories.

A detailed description of the short stories originally published in the paper are as follows: 1) "Hikayat Amal-Beramal" published in the newspaper Bintang Johar, No.2 18 January 1873; (2) "Ihajat Tanah Djawa", (3) "Tjeritera Saorang Saoedagar Jang Bernama Talip", (4) "Dari Khitsah Perdjalanan Abdoellah Pergi Meliat Tentehoewi", in the Çahabat Baik, No. 3, 1891; (5) "Tjerita Alksenoff Ataoe Satoe Soedagar jang Soedah Dihoekoem Tiada Berboeat Salah. Satoe tjerita dari negri Roes", (6) "Tjerita Di Toeloeng Saekor Andjing Satoe tjerita dari negeri Frans, (7) "Tjerita Henri Lest atau Habis Oedjan Tentoe Panas Lagi", (8) "Malaikat Djibrail dan Doea Orang Bersaoedara Satoe Dongeng dari Negeri Arab", (9) "Tjerita Nona Lizzij ataoe Saorang Prampoean Moeda Aloes Adat", (10) “Tjerita Prins Rajam Panahore Harganja Peroentoengan", (11) "Tjerita Si Marinem Ataoe Mata Gelap", were collected in Warna Sari, Penerbit Boekhandel Tan Swan Ie, Surabaia, 1912; (12) "Aspirant Luitenant Tan Ping Tjiat Dan Wak Tjoen Lee", contained Bok Tok, No 17 Ist Year, January 1914; (13) "Androclus dan Satoe Singa" published Penghiboer, No. 27 and 28, 3 and 10 January 1914; (14) "Apa jang
Terlanggar Mendjadi Mas (Bagiannja orang jang seraka)", published in Penghiboer, No. 28, 10 January 1914; (15) "Itoe Tasch Jang Terisi Dengan Inten", published in Bok Tok, No. 16, 17 January 1914; (16) "Satoe Pertjobaan Boeat Adjar Kenal Hatinja dari Ia Poenja Bakal Soeami", published in Bok Tok, No. 20, I, 14 February 1914; (17) "Kawanan Penipoe jang Amat Pinter", published in Penghiboer, No. 42, 18 April 1914; (18) "Tjerita dari Satoe Poehoen Mangga", published in Penghiboer, No. 44, 2 May 1914; (19) "Satoe Perboatan Djahat Dibales Dengen Kabaekan", published in Penghiboer, No. 47, 23 May 1914; (20) "Nona "Koelit Koetjing", published in Penghiboer, No. 48, 30 May 1914.

This fact shows that the emergence of Low Malay short stories had close links with the publication of newspapers at that time. At first, the publication of newspapers is done by the Dutch in the Dutch language to broadcast news in per merchandise trade in line with the activity carried out by Verenigde Oost Indische Compagnie (VOC) in the Dutch East Indies (Adam, 2003). Over the years, the publication of newspapers, not only with respect to news trade, but was also with regard to the problems of everyday life. Correspondingly, the rubrics in it, also increased. One of the sections that was deemed significant is the rubric of literature, especially short stories. However, as noted in the previous section, a short story published in this newspaper contained strong shades of journalism.

It is different with modern Indonesian literature that from the beginning by the publisher of Balai Pustaka has been published in the book form, which implies that the story in it is not news, but a different world, a story that characterizes itself as literature. The characteristic that thus has been able to make its position as literary works, works that have a high literary value.

Apparently, the emergence of the story in the form of a book was not for the influence of the Dutch colonial, but rather a legacy of the previous tradition, i.e. the tradition of classical Malay literature printed in manuscript form. With the rise of manuscript form, Malay literary classic ${ }^{4}$ circulated was not primarily due to the considerations of news value in it, but rather on the basis that the content of the value of literary or teaching that is deemed high. Thus, the policy 
of Balai Pustaka that published literary works Indonesia at the beginning in a book form was really just continuing the tradition of writing that have been there before.

\section{The World of the Story Tend Not about the Indonesian Archipelago.}

As part of the newspaper, short stories collected in Nona Koelit Koetjing seem inseparable from its position as a medium that acts as a traffic of information from one culture to another, in this case, is the Nusantara (archipelago) cultural heritage, to the culture of the other, and vice versa. Similar to the fact that the world reflected in it, was also the result of interaction between the various worlds that come from different cultures.

From the 20 short stories collected in it, 19 of them are stories that portray the association between one culture with another culture, reproduction of other cultures that are retold, and there is a short story about the natives of Indonesia. ("Hikajat Amal-Beramal", "Ihajat Tanah Djawa"), some were Arab-origin ("Tjerita Saorang Saoedagar yang Bernama Talip", "Malaikat Djibrail dan Doea Orang Bersaoedara Satoe Dongeng dari Negeri Arab"), some were Malay-origin ("Dari Khitsah Perdjalanan Abdoellah Pergi Melihat Tentehoewi"), some were Russian- origin ("Alksenoff ataoe Satoe Saoedagar jang Soedah Dihoekoem Tiada Berboeat Salah Satoe Tjerita dari Negeri Roes"), some were French- origin ("Di Toeloeng Saekor Andjing Satoe Tjerita dari Negeri Frans", "Kawanan Penipoe jang Amat Pinter"), some were Dutch -origin ("Henri Lest ataoe Habis Oejan Tentoe Panas Lagi", "Nona Lizzij ataoe Saorang Prampoean Moeda Aloes Adat", "Satoe Pertjobaan Boeat Adjar Kenal Hatinja dari Ia Poenja Bakal Soeami"), some were Indian-origin ("Prins Radjam Panahore Harganja Peroentoengan"), some were Archipelago-origin ("Si Marinem ataoe Mata Gelap", "Aspirant Luitenant Tan Ping Tjiat dan Wak Tjoen Lee" (telling about the Chinese in the Archipelago (Nusantara)), some were Italian-origin ("Androclus dan Satoe Singa", "Satoe Perboetan Djahat Dibales dengen Kebaekan"), some were European-origin ((“Apa jang Terlanggar Mendjadi Mas (Bagiannja orang jang seraka), "Itoe Tasch jang Terisi Dengen Inten", "Nona 'Koelit Koetjing'")). ${ }^{5}$ With the origin story of these various world portrayed in the story were also vary according to the cultures that sustain them. A story telling about its own world, that is "Si Marinem atau Mata Gelap" ("The SoCalled Marinem or Dark Eyes") authored by H.F.R Kommer depicts the so called dark-eyes character.

The presented world in the story of the diverse area above is really reasonable when taken in conjunction with the fact that the medium of the distribution was newspaper. That is because of newspapers were interested in the dissemination of information in many parts of the world, which for this purpose were parallel to the resale value and the newspaper's economic gains. One story tells about the world of itself, namely "Si Marinem ataoe Mata Gelap" by H.F.R. Kommer precisely described a character who ran amok.

The worlds where the stories originated with the diverse cultures above show that the stories collected in Nona Koelit Koetjing did not describe the expression of love for the motherland (tanah air) of the author, an expression of nationalist, who was one of the criteria of literature that can be recorded as a part of the history of modern Indonesian literature.

In contrast to the short stories above, the works of modern Indonesian literature recorded in the history of Indonesian literature told the story of their own environment with a series of events that convey good morals. "Si Marinem ataoe Mata Gelap", which tells the story of a soldier who wanted another soldier's wife and was not accomplished, continued with killing of both of them, would not be accepted if it was sent to the Balai Pustaka, because it was not considered to fight ignorance, which was therefore ,also, certainly inappropriate in the history of Indonesian literature. The choosing about the environment itself that conveyed good morals; it seems also with regard to the efforts of authors to portray the state of their socio-cultural condition, that it is a part that cannot be separated from the expression of love of their homeland.

\section{CONCLUSION}

The above description shows that the characteristics of the short stories collected in Low Malay's Nona Koelit Koetjing are not in accordance with the criteria of modern Indonesian 
literature. The mismatches also indicate the difference characteristics with modern Indonesian literature. The difference is what causes these short stories not chronicled as a part of the history of modern Indonesian literature.

Based on a similar fact, it becomes reasonable when Low Malay literature, in which its short stories were collected in Nona Koelit Koetjing as a part, is regarded as a separate literary tradition in the arena of literature at the time the Dutch East Indies, therefore, it also needs to be written in the history of literature of its own, without having to be integrated with the works of modern Indonesian literature.

\section{REFERENCES}

Adam, Ahmat. (2003). Sejarah Awal Pers dan Kebangkitan Kesadaran Keindonesiaan 18551913, translated from The Vernacular Press and the Emergence of Modern Indonesian Consciousness (1855-1913). Jakarta: Hasta Mitra, Pustaka Utan Kayu Perwakilan KITLVJakarta.

Bunanta, Murti. (1998). Problematika Penulisan Cerita Rakyat untuk Anak di Indonesia. Jakata: Balai Pustaka.

Damono, Sapardi Djoko, Melani Budianta, Saksono Prijanto, Erlis Nur Mujiningsih, Sri Sayekti, Widodo Djati, Dwi Pratiwi. (2005). Nona Koelit Koetjing: Antologi Cerita Pendek Indonesia Periode Awal (1870-an-1910-an). Jakarta: Pusat Bahasa Departemen Pendidikan Nasional.

Fang, Liaw Yock. (2011). Sejarah Kesusastraan Melayu Klasik. Jakarta: Yayasan Pustaka Obor Indonesia.

Faruk. (1999). Hilangnya Pesona Dunia, Siti Nurbaya, Budaya Minang, dan Struktur Sosial Kolonial. Yogyakarta: Yayasan Untuk Indonesia.

Faruk, Bakdi Soemanto, Bambang Purwanto. (2000). Perlawanan Atas Diskriminasi Rasial Etnik Konteks Sosial Ideologis Kritik Sastra Tionghoa Peranakan. Magelang: Indonesia Tera.

Habermas, Jurgen. (1990). The Philosophical Discourse of Modernity, twelve lecture. Massachussetts: The MIT Press Cambridge.

Hamzah, Amir. (1996). Sastra Melayu Lama dan RajaRajanya, cetakan ke-3. Jakarta: Dian Rakyat.

Kesastraan Melayu Tionghoa dan Kebangsaan
Indonesia, disunting oleh Marcus A.S. dan Pax Benedanto. (....). Jakarta: Kepustakaan Populer Gramedia.

Lan, Nio Joe. (1962). Sastra Indonesia-Tionghoa. Jakarta: Gunung Agung.

Mahayana, Maman. (2006). Bermain dengan Cerpen Apresiasi dan Kritik Cerpen Indonesia. Jakarta: Gramedia Pustaka Utama.

Pujiharto. (2014). "Polemik Mengenai Sastra PraIndonesia"(Polemic of Pre-Indonesian Literature), Bridging the Unbridgeable: Changing Paradigms in Malay-Indonesian Studies. Seoul Korea Selatan: Hankuk University of Foreign Studies.

Rosidi, Ajip. (1976). Ichtisar Sejarah Sastra Indonesia. Bandung.

Siregar, Bakri. (1964). Sedjarah Sastra Indonesia Modern. Jakarta: Akademi Sastra dan Bahasa Multatuli.

Salmon, Claudine. (1985). Sastra Cina Peranakan dalamBahasaMelayu.Jakarta:BalaiPustaka. . (2010). Sastra Indonesia Awal Kontribusi Orang Tionghoa (Indonesian Literature, Initial Contributions of The Chinese). Jakarta: Kepustakaan Populer Gramedia.

Stanton, Robert. (1965). An Introduction to Fiction. New York: Holt, Rinehart and Winston.

Sumardjo, Jakob. (2004). Kesusastraan Melayu Rendah Masa Awal. Yogyakarta: Galang Press.

Teeuw, A. (1980). Sastra Baru Indonesia Jilid I. Ende, Flores: Nusa Indah. (1989). Sastra Indonesia Modern II. Jakarta: Pustaka Jaya.

(2003). Tempoe Doeloe, Antologi Sastra Pra-Indonesia, cet. ke-2. Jakarta: Lentera Dipantara.

\section{(Endnotes)}

1 Nona Koelit Koetjing (2005). What is meant by Low Malay literature is literature written by using the Low Malay language. The authors were natives like R.M. Tirto Adisuryo, Mas Marco Kartodikromo; Chinese Peranakan, or the Netherlands. Along with the political developments that occurred in the 1920s, the term was narrowed to Chinese Malay literature or Malay-Chinese (Sumardjo, 2004: 2-3). The 
stories anthologized by Pramoedya Ananta Toer (2003) in the book Tempo Doeloe (Old Days), were also included in the category of Low Malay literature, but those have been selected based on the likelihood of anti-colonial material in it . This paper limit its study on the short stories collected in Nona Koelit Koetjing (2005)

2 What is meant here by the Low Malay literature is as a whole, not just one or two works of literature such as the work of Mas Marco Kartodikromo that have been mentioned in the books of Teeuw or Bakri Siregar

3 Indeed, not all authors of Low Malay literature were non-natives. There is also a native, like
R.M. Tirtoadisuryo, Mas Marco Kartodikromo (Sumardjo, 2004: 7). However, for the author of short stories collected in Nona Koelit Koetjing are all non-natives.

4 The book by Fang (2011) History of Classical Malay Literature discusses at length on classical Malay literature that has evolved in the Malay in the past.

5 The area of origin of this story is conjectural, that it is based on the assertion in the story regarding the origin, setting of the story or the characters. The most important aspect of these descriptions is that the origin of the story from various parts of the world. 